\title{
Editorial: Tribute to Eugene S. Simpson
}

\author{
Shlomo P. Neuman · Michael E. Campana \\ Guest Editors
}

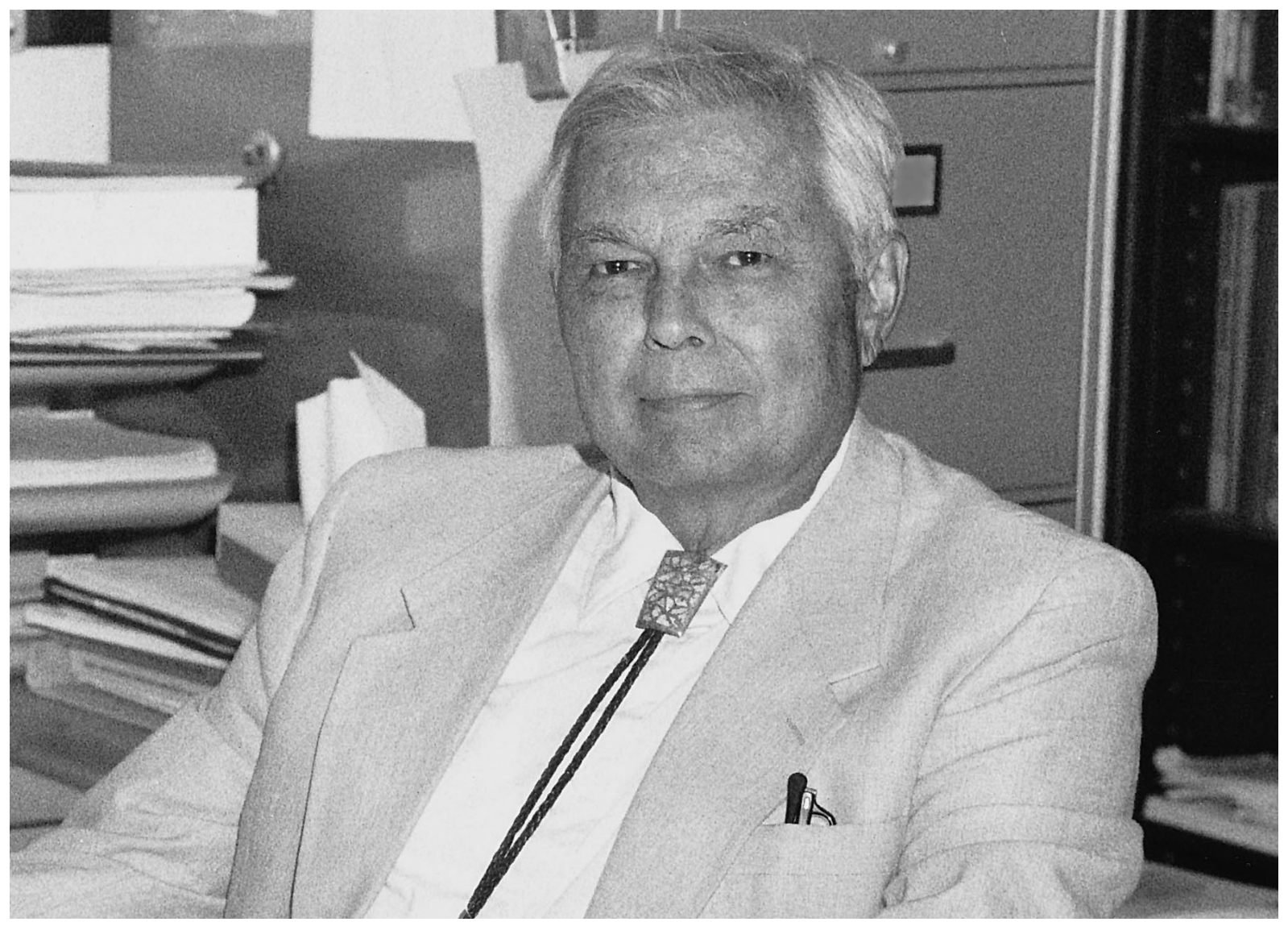

Eugene S. Simpson (1917-1995)

Key words profiles · Hydrogeology Journal · editorial

Shlomo P. Neuman ( $\square)$

Department of Hydrology and Water Resources, The University of Arizona, Tucson, AZ 85721, USA

Fax: + 1-520-621-1422

e-mail: neuman@hwr.arizona.edu

Michael E. Campana

Water Resources Administration Program, Department of Earth and Planetary Sciences, University of New Mexico,

Albuquerque, NM 87131-1116, USA
We dedicate this special issue of Hydrogeology Journal to the memory of its founding editor and first editorin-chief, the late Eugene S. Simpson. Gene died on December 12, 1995, at the age of seventy eight following a long and distinguished career as researcher and educator. With his departure, we all lost a valued colleague; many of us lost a close friend and beloved teacher. The papers in this special issue were authored by Gene's former colleagues and students as a tribute to his humanity and creative spirit. The wide range of topics covered by these papers reflects Gene's broad interests in the water sciences. 
Gene was born in Schenectady, New York, in 1917. He received a Bachelor of Science degree in civil engineering from the College of the City of New York in 1944 while helping to build port facilities and ammunition dumps for the U.S. Navy during World War II. In 1945, Gene took a position as hydrologist with the U.S. Geological Survey (USGS), where he helped investigate the groundwater resources of the northeastern United States. Soon he was recruited by C. V. Theis to join a newly formed USGS team charged with the investigation of hydrogeologic problems associated with existing and proposed nuclear facilities. Their pioneering work anticipated the need to protect groundwater from radionuclides and other contaminants at a time when few recognized the need to do so. This work helped kindle Gene's research interest in transport through porous media and isotope hydrology, to which he made important contributions throughout his career. In 1949, Gene obtained an M.A. and in 1960 a Ph.D. in Geology from Columbia University.

During 1960-62, Gene was assigned by the USGS to work at the Belgian Nuclear Research Center C.E.N. in Mol on hydrogeologic issues associated with the disposal of radioactive waste. A year later, Gene joined the newly formed Department of Hydrology and Water Resources at The University of Arizona in Tucson. As professor of geology, hydrology, and water resources, and as acting head of the department during 1974-75 and $1979-81$, Gene contributed in a major way toward the steady growth in size and reputation of the department.

In this endeavor, he made the study of hydrology intellectually challenging and rewarding for his students. One of them, Ike Winograd, recalls that "from time to time, Gene would use a simple but eloquent pedagogical tool to force students to really think about what they were reading. He would assign the class a controversial paper, plus the published discussions of it. He then instructed the students to list the explicit assumptions and the implicit assumptions in both the original paper and its critiques. Then students were asked to serve as individual judges of the merits of the compet- ing claims. Needless to say, one came away from such an exercise richer both in knowledge and in analytical thinking skills."

Gene's research at the university led to important new developments in the modeling of subsurface solute transport, the use of isotopes to estimate groundwater recharge, and the hydrogeology of fractured-rock terrains. For these contributions, Gene was made a Fellow of The Geological Society of America. His research on fractured rocks culminated in the XVII ${ }^{\text {th }}$ Congress on the "Hydrogeology of Rocks of Low Permeability," which he and the senior guest editor of this issue convened jointly at Tucson in 1985 . The Congress was sponsored by the International Association of Hydrogeologists (IAH). That same year, Gene retired.

Following his retirement, Gene remained professionally active by helping students complete their research theses and by serving the IAH. He was Secretary/Treasurer of the U.S. National Chapter from 198489 and President from 1989-92. It was during his term as President that Gene undertook to launch and edit the IAH journal Applied Hydrogeology, which later became Hydrogeology Journal. In 1989, the Hydrogeology Division of the Geological Society of America recognized Gene's many contributions by presenting him with its Distinguished Service Award. In 1993, Gene was made honorary member of the IAH in recognition of his outstanding scientific, editorial, and organizational work on behalf of the Association.

Throughout his life, Gene exuded warmth and optimism. A few months before his death, he sent his colleagues at the university a poem that reads, in part:

"Minutes that feed on simple pleasures ...

Reading comics on the patio,

Cool breeze, warm sun, I weep with delight.

My wife, my brother, here with love and comfort.

My pipe ... a simple pleasure."

He was speaking of his wife Diana and brother William.

At heart, Gene was a poet. He is sorely missed. 